\title{
Crystal Structure of trans-Bis(acetonitrile)dichloroplatinum(II)
}

\author{
Jürgen Kritzenberger, Hartmut Yersin* \\ Institut für Physikalische und Theoretische Chemie, Universität Regensburg, \\ D-93040 Regensburg
}

Klaus-Jürgen Range*, Manfred Zabel

Institut für Anorganische Chemie, Universität Regensburg, D-93040 Regensburg

Z. Naturforsch. 49b, 297 - 300 (1994); received July 13, 1993

Crystal Structure, Absorption Data, trans-Bis(acetonitrile)dichloroplatinum(II)

We have determined the crystal and molecular structure of trans-bis(acetonitrile)dichloroplatinum(II). Crystallographic data for trans $-\mathrm{Pt}\left(\mathrm{CH}_{3} \mathrm{CN}\right)_{2} \mathrm{Cl}_{2}$ : monoclinic, space group $\mathrm{P} 2{ }_{1} / c, a=5.0453(9), b=6.9896(5), c=11.962(1) \AA ⿻$ $, \beta=101.40(1)^{\circ}, V=413.5 \AA^{3}, Z=2, D_{x}=$ $2.796 \mathrm{~g} \mathrm{~cm}^{-3}, \mu(\mathrm{CuK} \alpha)=377.5 \mathrm{~cm}^{-1}, R=0.0502, w R=0.0529$ for 43 variables and 807 reflections with $\mathrm{F}>3 \sigma(\mathrm{F})$. The $\mathrm{Pt}$ atom is in a planar configuration with $\mathrm{N}$ and $\mathrm{Cl}$ atoms in trans positions. The shortest distance between two $\mathrm{Pt}$ atoms corresponds to the length of the crystallographic $a$-axis $(5.045 \AA)$. Additionally, we present optical absorption data of the cis- and trans-isomer.

\section{Introduction}

cis- $\mathrm{Pt}\left(\mathrm{CH}_{3} \mathrm{CN}\right)_{2} \mathrm{Cl}_{2}$ was first prepared by Hoffmann and Bugge [1] and its configuration was verified by different groups $[2,3]$ through a crystal structure determination. Fanizzi et al. [4] reported the kinetics of the conversion of the cis to the trans isomer in a solution of acetonitrile. We have used this conversion to prepare single crystals of the trans compound by slow crystallization from a dilute solution of cis- $\mathrm{Pt}\left(\mathrm{CH}_{3} \mathrm{CN}\right)_{2} \mathrm{Cl}_{2}$. Main subject of this paper is the investigation of the crystal and molecular structure of trans- $\mathrm{Pt}\left(\mathrm{CH}_{3} \mathrm{CN}\right)_{2} \mathrm{Cl}_{2}$. Additionally we report on spectroscopic properties of both isomers.

\section{Experimental}

Cis-Bis(acetonitrile)dichloroplatinum(II) was prepared from $\mathrm{K}_{2} \mathrm{PtCl}_{4}$ (Degussa) and acetonitrile (Merck, $>99.7 \%$ ) according to the procedure of Hoffmann and Bugge [1]. Crystals of both isomers of good quality for X-ray structure analysis and spectroscopic investigations were obtained by evaporation of the solvent from acetonitrile solutions applying different conditions of crystal growth. Crystals of the cis-compound were prepared using a highly concentrated solution of $c$ is $-\mathrm{Pt}\left(\mathrm{CH}_{3} \mathrm{CN}\right)_{2} \mathrm{Cl}_{2}$

\footnotetext{
* Reprint requests to Prof. Dr. H. Yersin or to Prof. Dr. K.-J. Range.

Verlag der Zeitschrift für Naturforschung,

D-72072 Tübingen

0932-0776/94/0300-0297/\$ 01.00/0
}

after a few days at room temperature. The crystal type was checked using the Weissenberg technique. On the other hand, single crystals of trans$\mathrm{Pt}\left(\mathrm{CH}_{3} \mathrm{CN}\right)_{2} \mathrm{Cl}_{2}$ were obtained by evaporation of the solvent of a solution of $\mathrm{cis}-\mathrm{Pt}\left(\mathrm{CH}_{3} \mathrm{CN}\right)_{2} \mathrm{Cl}_{2}$ in a refrigerator at $\mathrm{T}=6{ }^{\circ} \mathrm{C}$ over two months.

Elemental analysis was used to check the purity of the products. Analytical data calculated for $\mathrm{Pt}\left(\mathrm{CH}_{3} \mathrm{CN}\right)_{2} \mathrm{Cl}_{2}: \mathrm{C}, 13.8 ; \mathrm{N}, 8.1 ; \mathrm{H}, 1.7 \%$. Found: cis- $\mathrm{Pt}\left(\mathrm{CH}_{3} \mathrm{CN}\right)_{2} \mathrm{Cl}_{2}: \mathrm{C}, 13.9 ; \mathrm{N}, 8.0 ; \mathrm{H}, 1.8 \%$; trans- $\mathrm{Pt}\left(\mathrm{CH}_{3} \mathrm{CN}\right)_{2} \mathrm{Cl}_{2}: \mathrm{C}, 13.9 ; \mathrm{N}, 8.0 ; \mathrm{H}, 1.7 \%$.

The crystal structure of trans- $\mathrm{Pt}\left(\mathrm{CH}_{3} \mathrm{CN}\right)_{2} \mathrm{Cl}_{2}$ was determined from a single crystal $(0.90 \times 0.14 \times 0.08$ $\mathrm{mm}$ ) using an Enraf-Nonius CAD-4 diffractometer (CuK $\alpha, \lambda=1.5418 \AA$, graphite monochromator). Lattice parameters were refined from $2 \theta$ values of 18 reflections in the range $7^{\circ} \leq 2 \theta \leq 20^{\circ}$. Systematic absence of reflections $h 0 l(l \neq 2 n)$ and $0 k 0(k \neq 2 n)$ indicated the centrosymmetric space group $\mathrm{P} 2 / c$. Intensities were measured for $2^{\circ} \leq 2 \theta \leq 75^{\circ}$ using the $\omega-2 \theta$ scan technique (scan width $0.50^{\circ}+$ $0.15^{\circ} \tan \theta$ ). Three standard reflections indicated a $3.9 \%$ loss of intensity (linearly corrected) during data collection. Merging of the 1312 collected intensities $\left[\left(\sin \theta_{\max }\right) / \lambda=0.626 \AA^{-1} ;-6 \leq h \leq+6\right.$, $-8 \leq k \leq+6,-15 \leq l \leq+11]$ gave 807 unique reflections $\left(R_{\text {int }}=0.043\right)$ with $\mathrm{F}>3 \sigma(\mathrm{F})$ which were considered observed, and these were used for the calculations with the program system SHELX-76 [5].

The structure was solved by the heavy-atom technique. The $\mathrm{Pt}$ atom was located from the three-dimensional Patterson map. The positions of all other atoms were obtained by difference Fourier calculations. Refinement of the atomic coordinates and isotropic temperature factors resulted in $w R=$ 
0.126. At this stage a numerical correction for absorption (program DIFABS [6]) $\left(\mu=377.5 \mathrm{~cm}^{-1}\right)$ was applied before performing the final refinement (anisotropic for all atoms except $\mathrm{H}$ atoms, which were not located). Final $R=0.0502, w R=0.0529, w$ $=1 / \sigma^{2}(\mathrm{~F})$ for 834 absorption-corrected observed reflections. $(\Delta / \sigma)_{\max }<0.001$ in the final refinement cycle, 43 parameters. Maximum features in the final $\Delta \varrho$ map $+1.94,-3.41 \mathrm{e}^{-3}$. Atomic scattering factors and $\mathrm{f}^{\prime}, \mathrm{f}^{\prime \prime}$ values are taken from International Tables for X-ray Crystallography [7].

Optical absorption spectra of the complexes dissolved in acetonitrile (Merck, uvasol) were recorded with an Uvikon 960 (Kontron Co.) spectrophotometer.

\section{Results and Discussion}

\section{Structure}

The unit cell of trans- $\mathrm{Pt}\left(\mathrm{CH}_{3} \mathrm{CN}\right)_{2} \mathrm{Cl}_{2}$ is shown in Fig. 1, the corresponding cell parameters are summarized in Table I. Final atomic coordinates and equivalent isotropic displacement factors are given in Table II. Bond distances and important angles are summarized in Table III, calculated using the program SADIAN [8]*.

The $\mathrm{Pt}$ atom is coordinated in a quasi square-planar configuration with $\mathrm{N}$ and $\mathrm{Cl}$ atoms in trans-positions (Fig. 1). All these atoms lie strictly in the same plane according to crystallographic symmetry requirements.

\begin{tabular}{lc}
\hline $\mathrm{M}_{\mathrm{r}}\left(\mathrm{g} \mathrm{mol}^{-1}\right)$ & 348.10 \\
Space group & $\mathrm{P}_{2} / c$ \\
$a(\AA)$ & $5.0453(9)$ \\
$b(\AA)$ & $6.9896(5)$ \\
$c(\AA)$ & $11.962(1)$ \\
$\alpha\left({ }^{\circ}\right)$ & 90 \\
$\beta\left({ }^{\circ}\right)$ & $101.40(1)$ \\
$\gamma\left({ }^{\circ}\right)$ & 90 \\
$V\left(\AA^{3}\right)$ & 413.5 \\
$Z$ & 2 \\
$D_{x}\left(\mathrm{~g} \mathrm{~cm}^{-3}\right)$ & 2.796 \\
$\mu(\mathrm{CuK} \alpha)\left(\mathrm{cm}^{-1}\right)$ & 377.5 \\
$R$ & 0.0502 \\
$w R$ & 0.0529 \\
\hline
\end{tabular}

Table I. Crystal data for trans- $\mathrm{Pt}\left(\mathrm{CH}_{3} \mathrm{CN}\right)_{2} \mathrm{Cl}_{2}$.

* Lists of structure factors, bond distances and bond angles have been deposited at the Fachinformationszentrum Karlsruhe GmbH, D-76344 Eggenstein-Leopoldshafen. Copies may be obtained by quoting the depository number CSD 00000 , the name of the authors and literature citation.
Table II. Atomic coordinates and isotropic displacement factors $\left(\AA^{2}\right)^{\mathrm{a}}$.

\begin{tabular}{lllll}
\hline Atom & $x$ & $y$ & $z$ & $\mathrm{U}_{\text {eq }} / \mathrm{U}_{\text {iso }}$ b \\
\hline $\mathrm{Pt}$ & 0 & $1 / 2$ & $1 / 2$ & $0.0240(5)$ \\
$\mathrm{Cl}$ & $0.9424(8)$ & $0.2550(6)$ & $0.6208(3)$ & $0.0440(19)$ \\
$\mathrm{N}$ & $0.2333(22)$ & $0.3360(16)$ & $0.4304(9)$ & $0.0294(55)$ \\
$\mathrm{C} 1$ & $0.3647(27)$ & $0.2349(19)$ & $0.3881(12)$ & $0.0296(67)$ \\
$\mathrm{C} 2$ & $0.5280(34)$ & $0.1091(20)$ & $0.3352(14)$ & $0.0425(82)$ \\
\hline
\end{tabular}

a Numbers in parentheses are estimated standard deviations in the last significant digits; $b$ the equivalent isotropic $\mathrm{U}$ values for atoms refined anisotropically are defined as one third of the trace of the orthogonalized $\mathrm{U}_{\mathrm{ij}}$ tensor.

Table III. Interatomic distances $(\AA)$ and bond angles $\left({ }^{\circ}\right)^{a}$.

\begin{tabular}{lllll}
\hline \multicolumn{2}{l}{ Bond distances } & \multicolumn{3}{l}{ Bond angles } \\
\hline $\mathrm{Pt}-\mathrm{Cl}$ & $2.296(4)$ & $(\times 2)$ & $\mathrm{N}-\mathrm{Pt}-\mathrm{N}$ & 180.0 \\
$\mathrm{Pt}-\mathrm{N}$ & $1.944(10)$ & $(\times 2)$ & $\mathrm{Cl}-\mathrm{Pt}-\mathrm{Cl}$ & 180.0 \\
& & & $\mathrm{~N}-\mathrm{Pt}-\mathrm{Cl}$ & $89.6(3)$ \\
& & $\mathrm{N}-\mathrm{Pt}-\mathrm{Cl}$ & $90.4(3)$ \\
$\mathrm{N}-\mathrm{C} 1$ & $1.152(16)$ & & $\mathrm{Pt}-\mathrm{N}-\mathrm{C} 1$ & $177.8(10)$ \\
$\mathrm{C} 1-\mathrm{C} 2$ & $1.434(19)$ & & $\mathrm{N}-\mathrm{C} 1-\mathrm{C} 2$ & $180.0(24)$ \\
\hline
\end{tabular}

${ }^{a}$ Numbers in parentheses are estimated standard deviations in the last significant digits.

A comparison of bond lengths and angles with those of cis- $\mathrm{Pt}\left(\mathrm{CH}_{3} \mathrm{CN}\right)_{2} \mathrm{Cl}_{2}[2,3]$ shows only slight deviations. In the trans-compound the $\mathrm{Pt}-\mathrm{Cl}$ distance is $\approx 0.03 \AA$ longer, whereas the $\mathrm{Pt}-\mathrm{N}$ distance is $\approx 0.03 \AA$ shorter. The bond angles $\mathrm{N}-\mathrm{Pt}-\mathrm{Cl}$ exhibit only small differences from $90^{\circ}$ for both isomers $\left(1^{\circ}\right.$ for the cis- and $0.4^{\circ}$ for the trans-isomer, respectively). The shortest $\mathrm{Pt}-\mathrm{Pt}$ distances are $5.180 \AA$ for cis- $\mathrm{Pt}\left(\mathrm{CH}_{3} \mathrm{CN}\right)_{2} \mathrm{Cl}_{2}$ and $5.045 \AA$ for trans- $\mathrm{Pt}\left(\mathrm{CH}_{3} \mathrm{CN}\right)_{2} \mathrm{Cl}_{2}$. For the trans-isomer the distance between two $\mathrm{Pt}$ atoms corresponds to the lengths of the $a$-axis.

\section{Optical absorption}

The absorption spectra of the cis- and trans-isomers dissolved in acetonitrile were recorded using concentrations between $10^{-5}$ and $10^{-2} \mathrm{~mol} \mathrm{l}^{-1}(\mathrm{~T} \approx$ $300 \mathrm{~K})$. The half-life of the isomerization of cis$\mathrm{Pt}\left(\mathrm{CH}_{3} \mathrm{CN}\right)_{2} \mathrm{Cl}_{2}$ into trans- $\mathrm{Pt}\left(\mathrm{CH}_{3} \mathrm{CN}\right)_{2} \mathrm{Cl}_{2}$ is $\approx 14 \mathrm{~h}$ [4]. Therefore, all spectra were recorded using freshly prepared solutions. The energy positions, halfwidths and $\varepsilon$-values of all observed absorption 


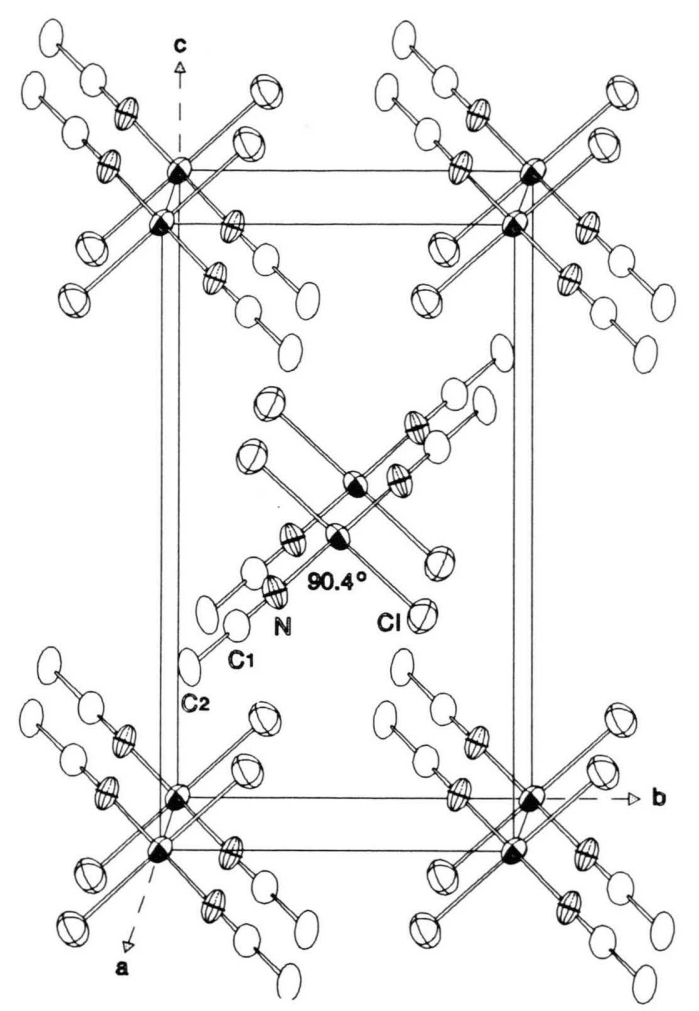

Fig. 1. ORTEP plot of the trans- $\mathrm{Pt}\left(\mathrm{CH}_{3} \mathrm{CN}\right)_{2} \mathrm{Cl}_{2}$ unit cell (protons are not shown).

bands are listed in Table IV. Reports on the electronic structure of diaminedichloroplatinum(II) are given in the literature $[9,10]$. For $\mathrm{Pt}\left(\mathrm{NH}_{3}\right)_{2} \mathrm{Cl}_{2}$ absorption bands at $45500 \mathrm{~cm}^{-1}$ (cis-isomer) and at $46500 \mathrm{~cm}^{-1}$ (trans-isomer) are both assigned to $5 \mathrm{~d} \rightarrow 6 \mathrm{p}$ transitions $[9,10]$. If $\mathrm{NH}_{3}$ is replaced by the $\mathrm{CH}_{3} \mathrm{CN}$ ligand, like in $\mathrm{Pt}\left(\mathrm{CH}_{3} \mathrm{CN}\right)_{2} \mathrm{Cl}_{2}$, the $\pi^{*}$ orbitals of the acetonitrile ligands will interact with a Pt $6 \mathrm{p}$ orbital, and this will lead to a red-shift of the LUMO. Thus, we expect an absorption with a high $\varepsilon$-value at lower energy than in $\mathrm{Pt}\left(\mathrm{NH}_{3}\right)_{2} \mathrm{Cl}_{2}$ for both isomers. Indeed, the spectra exhibit an absorption at $\approx 42900 \mathrm{~cm}^{-1}\left(\varepsilon<80001 \mathrm{~mol}^{-1} \mathrm{~cm}^{-1}\right)$ for cis$\operatorname{Pt}\left(\mathrm{CH}_{3} \mathrm{CN}\right)_{2} \mathrm{Cl}_{2}$ and at $\approx 43050 \mathrm{~cm}^{-1}(\varepsilon \approx 42001$ $\left.\mathrm{mol}^{-1} \mathrm{~cm}^{-1}\right)$ for trans- $\mathrm{Pt}\left(\mathrm{CH}_{3} \mathrm{CN}\right)_{2} \mathrm{Cl}_{2}$. Thus, we assign these absorption bands to $\left(5 \mathrm{~d} \rightarrow 6 \mathrm{p}, \pi^{*}\right)$ transitions for both isomers. Absorption bands with $\bar{v}<$ $40000 \mathrm{~cm}^{-1}$ of $\mathrm{Pt}\left(\mathrm{NH}_{3}\right)_{2} \mathrm{Cl}_{2}$ were assigned to $\mathrm{d}-\mathrm{d}$ transitions $[9,10]$. According to these results and to the observed $\varepsilon$-values of the absorption bands below $40000 \mathrm{~cm}^{-1}$ of cis- and trans- $\mathrm{Pt}\left(\mathrm{CH}_{3} \mathrm{CN}\right)_{2} \mathrm{Cl}_{2}$ (Table IV) we assign these transitions also to be
Table IV. Absorption bands ${ }^{\mathrm{a}}$ in cis- and trans$\mathrm{Pt}\left(\mathrm{CH}_{3} \mathrm{CN}\right)_{2} \mathrm{Cl}_{2}$.

\begin{tabular}{lcl}
\hline $\bar{v}_{\max }\left[\mathrm{cm}^{-1}\right]$ & $\varepsilon\left[1 \mathrm{~mol}^{-1} \mathrm{~cm}^{-1}\right]$ & halfwidth $\left[\mathrm{cm}^{-1}\right]$ \\
\hline cis- $\mathrm{Pt}\left(\mathrm{CH}_{3} \mathrm{CN}\right)_{2} \mathrm{Cl}_{2}$ & \\
22500 & $15^{\mathrm{b}}$ & 2500 \\
27300 & 40 & 4500 \\
30600 & 150 & 4000 \\
36350 & 260 & 3000 \\
42900 & 8000 & 2200 \\
44500 & shoulder & \\
& & \\
trans- $\mathrm{Pt}\left(\mathrm{CH}_{3} \mathrm{CN}\right)_{2} \mathrm{Cl}_{2}$ & \\
23500 & $77^{\mathrm{b}}$ & 2500 \\
27000 & 15 & 3000 \\
31150 & 50 & 3000 \\
39800 & 250 & 1700 \\
43050 & 4200 & 1300 \\
44650 & shoulder & \\
\hline
\end{tabular}

a Experimental errors: $\pm 100 \mathrm{~cm}^{-1}$ for energy positions and halfwidths and $\pm 10 \%$ for $\varepsilon$-values; ${ }^{b}$ from single crystal absorption spectra using the crystallographic densities and the crystal thicknesses d [cis-isomer: $2.803 \mathrm{~g} \mathrm{~cm}^{-3}[2], \mathrm{d} \approx 6 \mu \mathrm{m}$; trans-isomer: $2.796 \mathrm{~g} \mathrm{~cm}^{-3}$ (Table I), $\mathrm{d} \approx 10 \mu \mathrm{m}]$. All other values are from solution spectra.

mainly of $5 \mathrm{~d} \rightarrow 5 \mathrm{~d}$ character. A comparison of the results of the cis- and the trans-isomer are an indication of the fact that transitions in systems with a center of inversion are symmetry forbidden. Thus, the $\varepsilon$-values of the $\mathrm{d}-\mathrm{d}$ transitions are smaller for the trans-isomer.

\section{Acknowlegement}

We thank the DEGUSSA AG (Hanau) for a donation of $\mathrm{K}_{2}\left[\mathrm{PtCl}_{4}\right]$ and the Verband der Chemischen Industrie for financial support. 
[1] K. A. Hoffmann, G. Bugge, Ber. 40, 1772 (1907).

[2] F. D. Rochon, R. Melanson, H. E. Howard-Lock, C. J. L. Lock, G. Turner, Can. J. Chem. 62, 860 (1984).

[3] G. R. Newkome, V. K. Gupta, F. R. Fronczek, Acta Crystallogr. C 42, 1643 (1986).

[4] F. P. Fanizzi, F. P. Intini, L. Maresca, G. Natile, J. Chem. Soc. Dalton Trans. 1990, 199.

[5] G. M. Sheldrick, SHELX-76. Program for Crystal Structure Determination. Univ. of Cambridge, England (1976).

[6] N. Walker, D. Stuart, Acta Crystallogr. A 39, 159 (1983).
[7] International Tables for X-ray Crystallography, Vol. IV, Kluwer Academic Publishers, Dordrecht, Birmingham: Kynoch Press (1974).

[8] W. H. Baur, G. Wenninger, SADIAN. Program for calculation of atomic distances and angles in crystal structures. Univ. of Illinois, USA (1969).

[9] H. H. Patterson, J. C. Tewksbury, M. Martin, M.-B. Krogh-Jespersen, J. A. LoMenzo, H. O. Hooper, A. K. Viswanath, Inorg. Chem. 20, 2297 (1981).

[10] J. Chatt, G. A. Gamlen, L. E. Orgel, J. Chem. Soc. 1958, 486. 